\title{
Integrating Audit System Of AGC, ISO14001, ISO45001 to Improve Implementation of the Management Systems in Leading Heavy Equipment Companies
}

\author{
Satriyo Widy Prasetyo \\ ${ }^{1}$ United Tractors, Cakung - Indonesia \\ ${ }^{2}$ Master of Mechanical Engineering \\ Swiss German University \\ Tangerang City, Indonesia \\ satriyow@unitedtractors.com
}

Henry Nasution

Master of Mechanical Engineering

Swiss German University

Tangerang City, Indonesia

henry.nasution@sgu.ac.id

\author{
Gembong Baskoro \\ Master of Mechanical Engineering \\ Swiss German University \\ Tangerang City, Indonesia \\ gembong.baskoro@sgu.ac.id
}

\author{
Dena Hendriana \\ Master of Mechanical Engineering \\ Swiss German University \\ Tangerang City, Indonesia \\ dena.hendriana@sgu.ac.id
}

Hanny J. Berchmans

Master of Mechanical Engineering

Swiss German University

Tangerang, Indonesia

hannyjberchmans2020@gmail.com

\begin{abstract}
In running a business in a company, a management system is needed to determine every company's decision making by considering environmental protection and development, occupational safety and health. By applying AGC (occupational safety and health and environment), ISO 14001 (Environment), ISO 45001 (occupational safety and health) and other management systems. With so many management systems implemented by companies, there is a need for integration between management systems, especially during audits. With the existence of an integrated internal audit tool, it can be more effective and efficient in running a management system that is widely implemented. Duplication of work and documents can be avoided in conducting internal audits. Therefore, it is necessary to have an integrated internal audit tool for readiness to conduct an audit from external parties.
\end{abstract}

Keywords - management system, audit, integration, AGC, ISO 14001, ISO 45001.

\section{INTRODUCTION}

With the development of the economy and technology in various sectors, it is encouraging the need for heavy equipment. Therefore this company is ready to provide a solution related to this matter. This company is the largest and leading heavy equipment distributor in Indonesia, providing products from world-renowned brands such as Komatsu, UD Trucks, Scania, Bomag, Tadano, and Komatsu Forest. On October 13, 1972, Initial public offering on the Jakarta Stock Exchange and Surabaya Stock Exchange on September 19, 1989.

From Fig. 1 and Fig. 2 of work accidents in Indonesia and work accidents in mines where the company plays a major role in mining, there is an increase in work accidents so that companies control work accidents through the implementation of a dual management system to reduce the number of accidents. In Strategic Direction and Strategic Implementation, the company division the key to the success of the effective collaboration, one of which is Quality management systems and LK3, so it is expected to be one of the factors to achieve sustainable business.

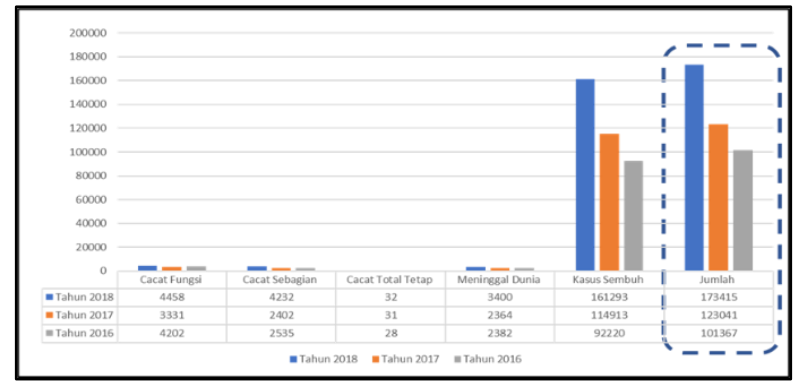

Fig. 1. Work accident in Indonesia 2016 - 2018

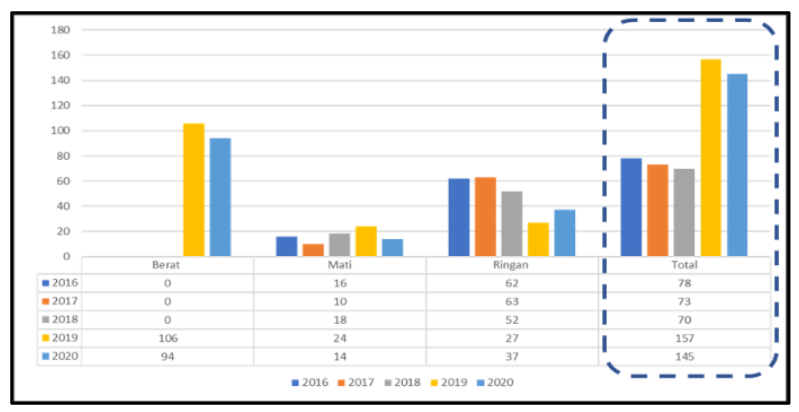

Fig. 2. Work accident in mine $2016-2020$ 
There are several problems if the system is not integrated, for example for the preparation of documents, including independent or not optimally integrated Procedures (SOPs), causing duplication/integration of typical documents or manufacturing authorities at the corporate or branch level and operational locations. Costs and time spent are relatively higher because each region incurs costs for implementation, auditing and certification as well as duplication of work for the preparation and audit processes.

With the conditions like the above, research is needed to model system integration from the latest ISO 14001, 45001 with AGC as a system characterized as ASTRA personnel that needs to be applied not only at the head office but at branches and company sites as an internal audit tool.

The Objectives of this work are:

1. To create an integrated management system in accordance with the conditions and characteristics of the company

2. To facilitate internal auditors in auditing the health and safety and environmental management systems of AGC, ISO 14001, ISO 45001 at the head office so that there is no duplication of work and documents

3. To improve the efficiency of time, cost and number of people in implementing internal audits of occupational health and safety management systems with methodology PDCA cycle.

\section{LITERATURE REVIEW \& RESEARCH METHODOLOGY}

\section{A. Literature Review}

ASTRA Green Company (AGC) is a company that has management that consciously puts into consideration the protection and development of the environment, safety and health "Stake Holder" in every business decision making as a manifestation of responsibility and efforts to make a positive contribution to society and sustainable development as shown in Fig. 3.

Green Company consists of 4 (four) main components that are an integral part of the decision making and basic corporate programs, and are simultaneously implemented properly, namely:

1. Green Strategy

2. Green Process

3. Green Product

4. Green Employee

The combination of the four components will produce adequate "Environment, Health and Safety" performance and in accordance with the prevailing principles in the world of business, state, and community life. From the above criteria the flow diagram can be described as follows:

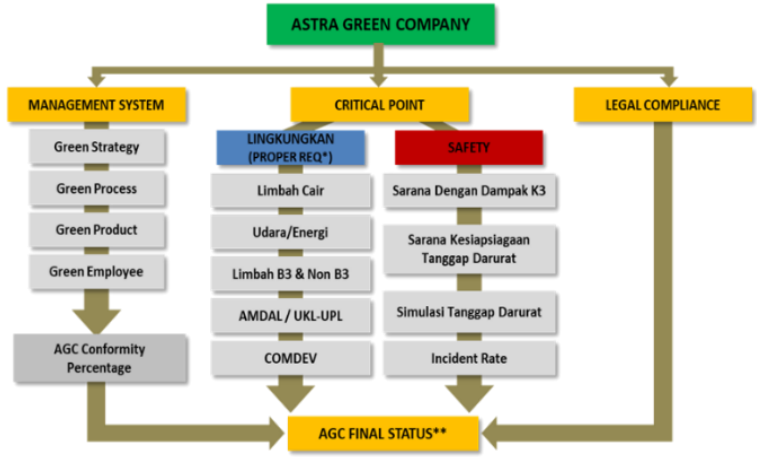

Fig. 3. Non high risk AGC rating system

ISO 45001 is an International Standard that specifies requirements for an occupational health and safety $(\mathrm{OH} \& \mathrm{~S})$ management system, with guidance for their use, to enable organizations to proactively improve $\mathrm{OH} \& \mathrm{~S}$ performance in preventing injuries and ill health. For companies using both this standard, will be a stronger, better, higher, and safer company. The following clauses on ISO 45001:
1. Scope
2. Normative references
3. Terms of definition
4. Context of organization
5. Leadership
6. Planning
7. Support
8. Emergency preparedness
9. Performance evaluation
10. Improvement

The Environmental Management System (EMS) is also known as an internationally popular term, namely EMS (Environment Management System). The application or implementation of ISO 14001 EMS in many companies in Indonesia is generally under the responsibility of a special division to deal with environmental issues. Companies/organizations are also required to understand all rules and laws regarding the environment. The implementation of ISO 140012015 must be accompanied by a commitment from the company management. ISO 140012015 has a clause that is easy to integrate as follows:
1. Scope
2. Normative references
3. Terms of definition
4. Context of organization
5. Leadership
6. Planning
7. Support
8. Emergency preparedness
9. Performance evaluation
10. Improvement

The definition of an integrated audit is an audit process that uses an audit process and an audit program for a Quality Management System (Q), Environmental Management System (E), Health and Safety Management 
System (HS), Food Safety Management System (FSMS) in a container. The integrated audit process (Fig. 4) uses an integrated audit checklist and auditors who are able to perform audits in an integrated manner.

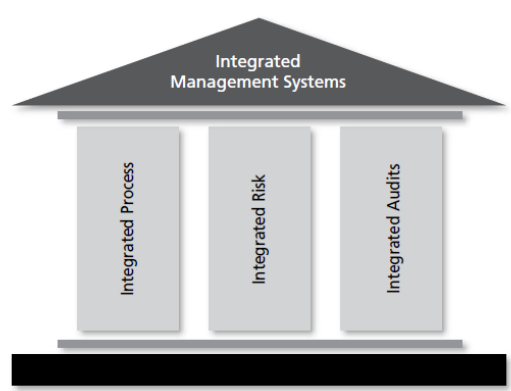

Fig. 4. Three pillars of an integrated management system

Is a standard issued by BSI (British Standard Institute) which will be used by a company that will implement an integrated management system. PASS 99 is a general requirement that is used as a framework for creating an integrated system. With this, the company can encourage its organization to be able to use several management systems to become a single holistic one, enabling the company to run more effectively and efficiently:

1. Scope

2. Normative references

3. Terms of definition

4. Context of organization

5. Leadership

6. Planning

7. Support

8. Emergency preparedness

9. Performance evaluation

10. Improvement

\section{B. Research Methodology}

Referring to Fig 5, this study uses comparative and qualitative research methods to calculate the efficiency of an integrated internal audit tool. The following follows the flow of the research method used to calculate the efficiency of using an integrated internal audit tool. starting from the explanation of the AGC clauses, ISO 14001 and ISO 45001 , then the clauses of each management system in the same comparison and mapped in the PDCA so that they can be integrated because the management system at ISO is made based on the approach of the PDCA system. After the integration is made, data interpretation from integrated clauses is made so that an integrated internal audit tool can be made. From the finished internal audit tool, time, number of auditors, and wages will be measured so that we get efficiency from the existing data.

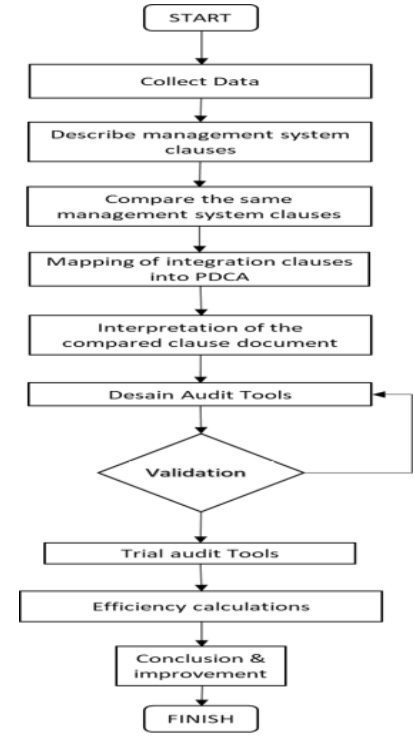

Fig. 5. Flow diagram of research

ISO 45001 In clauses 1 and 3 are background information that contains information, while clause 4 in the organizational context focuses on the system processes and requirements required by the organization to achieve a goal. Clauses 5 to 10 are general clauses in the ISO management system. ISO 14001 (Fig. 6) is closely related to the topic of the environment and there are processes that must be defined, implemented and maintained. Iso 14001
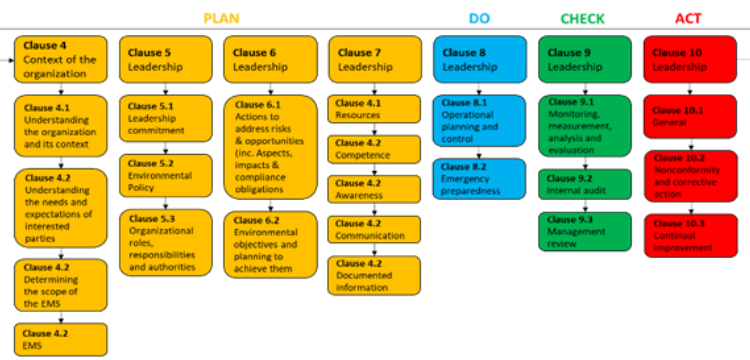

Fig. 6. PDCA ISO 14001

This management system has 10 clauses and 60 clauses. For details, see the ISO 45001 structure as shown in Fig. 7. In the first three clauses, useful information is related including terms and definitions that are the background for ISO. Then in clause 4, the organizational context focuses on the system processes and requirements needed by the organization to achieve a goal by understanding the context of the organization and its operations. Clause 4 determines the requirements for determining the scope of the system and planning the system to be implemented. Clauses 5 to clause 10 are common standards in management systems. 


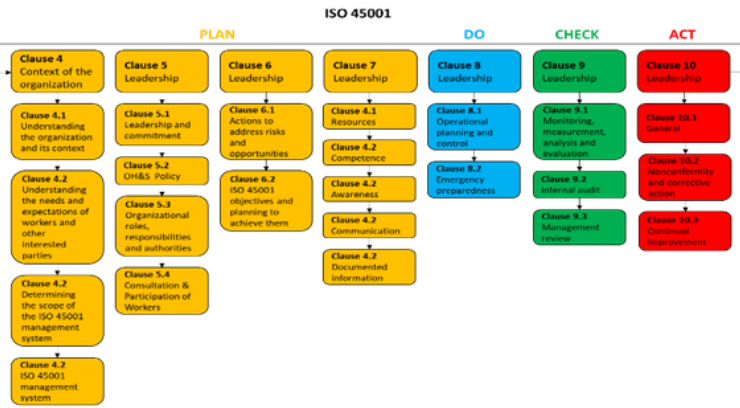

Fig. 7. PDCA ISO 45001

After the distribution of the clauses of the AGC, ISO 14001 , ISO 45001 management systems, the next step is to compare the same clauses between the three management systems as shown in Fig. 8. So that we get integration between existing clauses in the management system being compared. From the comparisons made, the same or unequal clauses will be obtained.

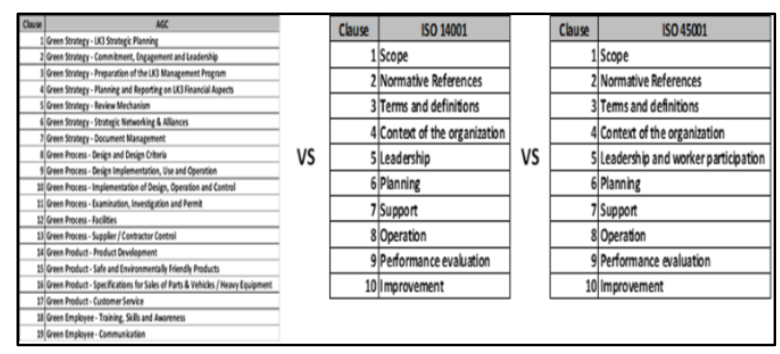

Fig. 8. Comparison of the same clause

The internal audit tool creates formulas that are compatible with the AGC scoring system. There are modifications to the AGC scoring system. You could say, if the documentary evidence requested is the same then the questions will be combined, so that when answering the requested evidence will provide an assessment (Fig. 9) of several clauses that are combined. So that interpretations of the clauses that have been combined can be made. On the other hand, we can map the AGC to ISO using the PDCA Approach

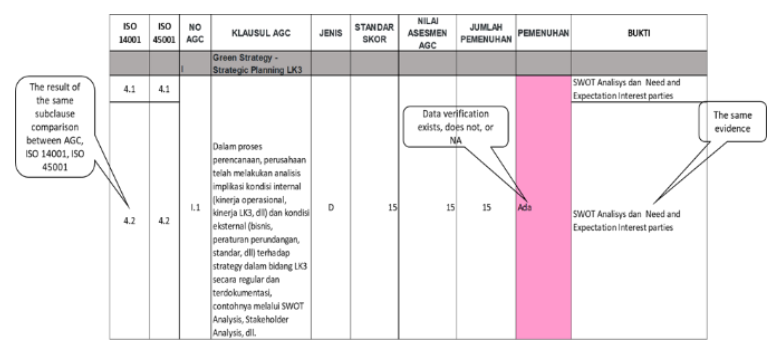

Fig. 9. Assessment system on internal audit tools

Fig. 10 is showing internal audit tool is made offline first using Microsoft Excel than to make it easier to carry out internal audits it is strengthened online using Google Forms by uploading the appropriate data requested by the system integration clause. On the other hand, the assessment of the document can be done in the cloud so that the results of the audit score can come out automatically

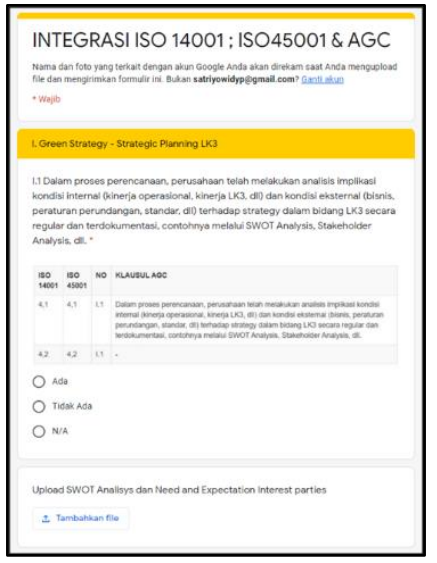

Fig. 10. Design online internal audit tools

\section{RESULT}

From the calculation of the same clause comparison between ISO 14001 and AGC, the value is $82 \%$ as shown in Fig. 11. Judging from the chart above, ISO 14001 scores the highest in green strategy, Green Product, Legal Compliance, and CP Environment. CP Safety and Green Process get the lowest score because ISO 14001 focuses more on the environment.

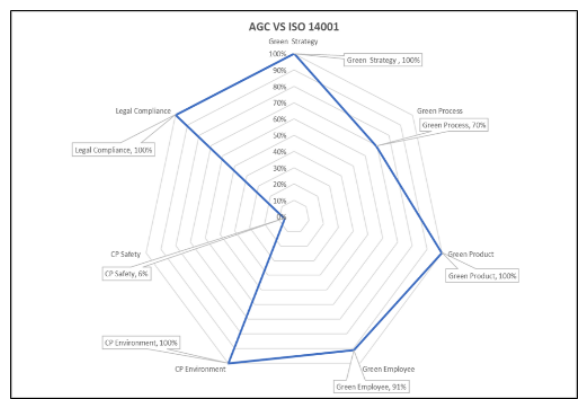

Fig. 11. AGC vs ISO 14001

From the calculation of the same clause comparison between ISO 45001 and AGC, the value is $84 \%$ as shown in Fig. 12. Judging from the chart above, ISO 45001 scores the highest in green strategy, Green Process, Legal Compliance, and CP safety. The CP Environment and green products get the lowest scores because ISO 45001 focuses more on occupational safety and health.

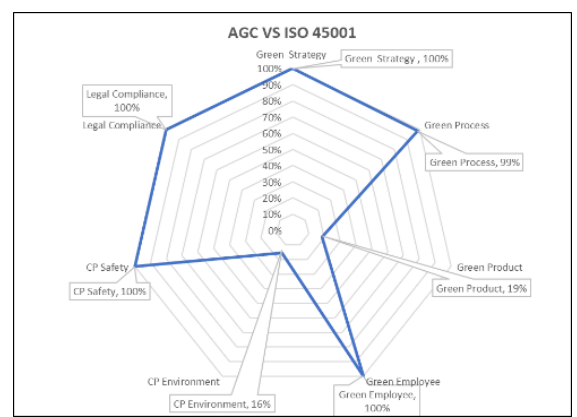

Fig. 12. AGC vs ISO 45001 
For AGC mapping to ISO 14001 in the PDCA cycle obtained:

- The clause plan in ISO 14001 has 4 clauses, while in the AGC there are 131 clauses.

- Do clauses in ISO 14001 there is 1 clause, while in AGC there are 154 clauses.

- Check the clause in ISO 14001 there is 1 clause, while in the AGC there are 75

- Act clause in ISO 14001 there is 1 clause, while in AGC there are 11 clauses.

For AGC mapping to ISO 14001 in the PDCA cycle obtained:

- The clause plan in ISO 14001 has 4 clauses, while in the AGC there are 132 clauses.

- Do clauses in ISO 14001 there is 1 clause, while in AGC there are 164 clauses.

- Check the clause in ISO 14001 there is 1 clause, while in the AGC there are 72

- Act clause at ISO 14001 there is 1 clause, while in AGC there are 12 clauses.

Validation is needed from experts to verify that these tools can be used. Validation was carried out by two experts from outside the company and from within the company. The expert with the name of Mr. Mujoko from internal company who became one of the contributors in the preparation of AGC as validator one (Fig. 13) and Mr. Andie from external company who has a consultant related to system management as validator two as shown in Fig 14.

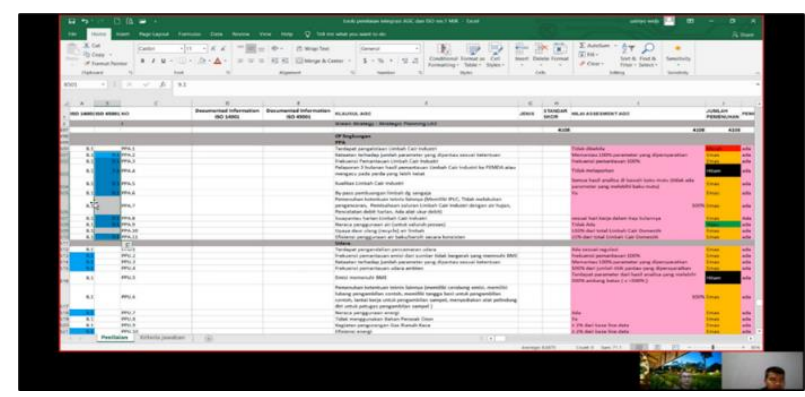

Fig. 13. Validation with one validator

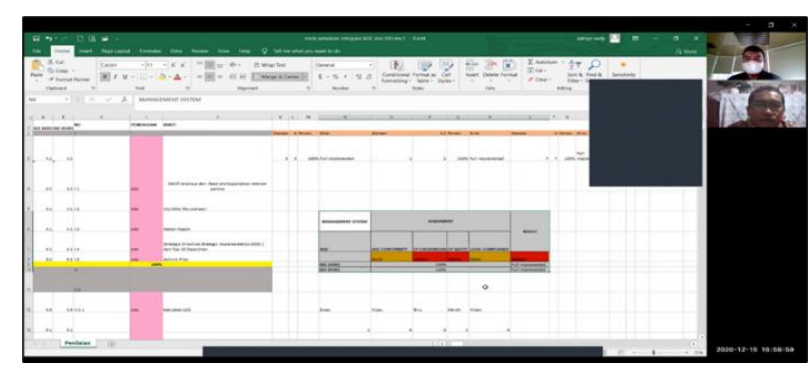

Fig. 14. Validation with two validator

From the results of the validation of the internal audit tool (Fig. 15) that has been done, it can be concluded that it can be used, but there is a revision in the clause comparison.

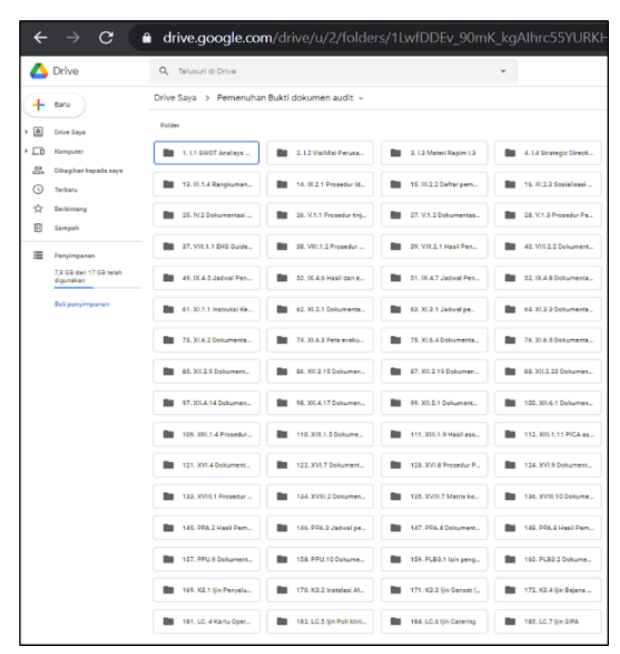

Fig. 15. Data interpretation of internal audit clauses

The internal audit tool testing was conducted by one internal auditor and one auditee as shown in Fig. 16. Internal audit used Microsoft Teams as the media for auditing implementation. From these trials, the data obtained:

- Internal auditors are conducted by one auditor

- One person audited

- Total time required 3 hours 29 minutes

- Gold AGC results

- ISO 14001 100\% Full Implemented Results

- ISO 45001 99,495 Full Implemented Results

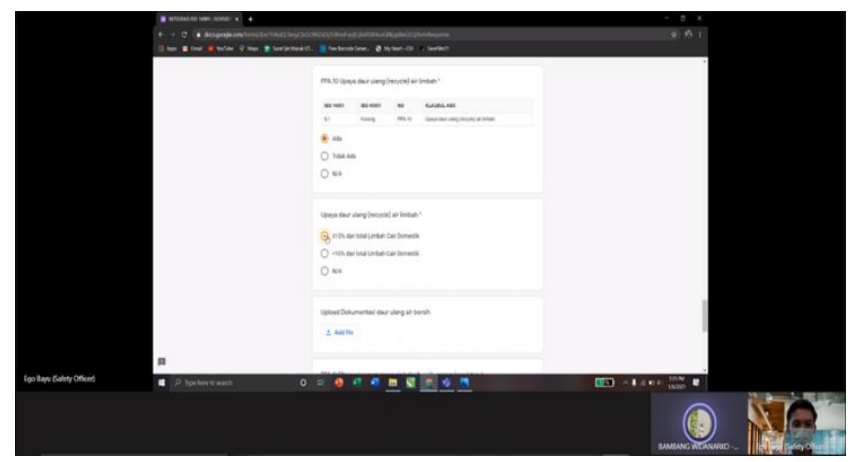

Fig. 16. Documentation when testing the internal audit tool

Thus, the calculation of efficiency can be done using existing data in the company's internal compared with trial data. With this calculation, it is expected to know how much efficiency can be done in terms of the number of auditors conducting internal audits, the amount of costs incurred by the company to pay employees, and the time required to carry out internal audits. The following are the results of efficiency calculations using an integrated internal audit tool is showing in Table 1. 
TABLE I

CALCULATION OF THE EFFICIENCY OF USING INTEGRATED INTERNAL AUDIT TOOLS

\begin{tabular}{crrr}
\hline $\begin{array}{c}\text { Management } \\
\text { system }\end{array}$ & $\begin{array}{c}\text { Time } \\
\text { Efficiency }\end{array}$ & $\begin{array}{c}\text { Auditor } \\
\text { Efficiency }\end{array}$ & $\begin{array}{c}\text { Wage } \\
\text { Cost } \\
\text { Efficiency }\end{array}$ \\
\hline AGC & $78 \%$ & $50 \%$ & $89 \%$ \\
\hline ISO 14001 & $78 \%$ & $50 \%$ & $89 \%$ \\
\hline ISO 45001 & $78 \%$ & $50 \%$ & $89 \%$ \\
\hline
\end{tabular}

\section{CONCLUSIONS ANDRECOMMENDATIONS}

\section{A. Conclusions}

1. The clause that AGC cannot integrate into ISO 14001 is 83 clauses AGC, while AGC to ISO 45001 is 74 clauses.

2. Integrate AGC, ISO 14001, ISO 45001 by means of a comparative approach from the same clause using the High-level Structure approach and the PDCA cycle to serve as the basis for integration.

3. From the results of the test calculations that have been carried out, the efficiency data obtained is $78 \%$ time efficiency, $50 \%$ number of auditors, $89 \%$ cost.

4. With an integrated internal audit tool, it makes the audit easier to implement.

5. The interpretation data made makes the accuracy of the data for audit evidence more in line with what is expected by the auditor and is always updated.

6. From this research data is expected to improve the implementation of the company's management system.

\section{B. Recommendations}

For academics:

1. This research can still be developed if other management systems are added to be integrated.

2. This method can be used again for research making integration systems in addition to the management system used in this study

3. This the results of this research, analysis can be carried out so that improvements or innovations can be made related to this research

For professionals:

1. Creating an application that stores data regarding the centralized management of occupational safety and health and the environment which has adjusted the audit evidence needs based on AGC. The data will become a data bank during the audit and can be accessed by all branches and sites.

2. With the creation of a data bank application, an application for auditing is added so that when uploading data to the application, it will also get the audit value for several management systems based on the evidence that has been uploaded.

3. When answering evidence of "there", in the future, the program is obliged to upload the required evidence first and then be able to answer "there" in each clause.
4. In the implementation of an internal audit, the results will interpret the results of the audit that will be carried out by external parties. Therefore, an external audit remains the company's obligation and makes it a validator of the quality of internal audit results.

\section{REFERENCES}

[1] E. Sarwono, M. R. Deliansyah, E. S. Wibowo, and A. A. Utomo, Green Company Pedoman Pengelolaan Lingkungan, Keselamatan dan Kesehatan Kerja, PT Astra Internasional Tbk: Jakarta, 2002

[2] R. Deliansyah, et. al., Panduan Kriteria Asesmen Astra Green Company, PT Astra Internasional Tbk: Jakarta, 2004

[3] C. Kymal, G. Gruska, and R. D. Reid, Integrated Management Systems QMS, EMS, OHSMS, FSMS including Aerospace, Service, Semiconductor/Electronics, Automotive, and Food. Milwaukee: Lynelle Korte, 2015.

[4] M. Majerník, N. Daneshjo, J. Chovancová, and G. Sančiová, "Design of integrated management systems according to the revised ISO standards," Polish Journal of Management Studies, pp. 135-143, 2017

[5] B. Barafort, A. L. Mesquida, and A. Mas, "Integrating risk management in IT settings from ISO standards and management systems perspectives," Computer Standards \& Interfaces, 2016

[6] J. L. Kraus, J. Grosskopf, Auditing Integrated Management Systems: Considerations and Practice Tips, Wiley InterScience, pp. 7-16, 2008.

[7] M. F. Rebelo, G. Santos, and R. Silva, "A generic model for integration of quality," Environment and Safety Management Systems. TQM Journal, pp. 143-159, 2014.

[8] M. Olaru, D. Maier, D. Nicoară, and A. Maier, "Establishing the basis for development of an organization by adopting the integrated management systems: comparative study of various models and concepts of integration. Procedia - Social and Behavioral Sciences, pp. 693 - 697, 2014.

[9] V. T. Nunhes, M. Bernardo, and J. O. Oliveira, "Guiding principles of integrated management systems: towards unifying a starting point for researchers and practitioners," Journal of Cleaner Production, pp. 977 - 993, 2019.

[10] J. Domingues, P. Sampaio, and P. Arezes, "Analysis of integrated management systems from various perspectives," Total Quality Management \& Business Excellence, pp. 1-24, 2014.

[11] M. Gianni and K. Gotzamani, K. "Management systems integration: lessons from an abandonment case," Journal of Cleaner Production, pp. 1 - 12, 2014.

[12] PT Astra Internasional, Astra Green Company and Astra Friendly Company Online Assessment Platform, 2020. Retrieved from Green Company: https://agction.id

[13] I. O. Standardization, ISO, 2020. Retrieved from ISO 45001:2018: https://www.iso.org/standard/63787.html

[14] I. O. Standardization, ISO, 2020. Retrieved from ISO 14001:2015: https://www.iso.org/standard/60857.html

[15] PT United Tractors Tbk, United Tractors, 2020. Retrieved from Report: https://www.unitedtractors.com/en/report/ 